\title{
UPAYA ANAK JALANAN DALAM MEMPEROLEH PENDIDIKAN ISLAM
}

\author{
Nur Setyaningrum, M. S.I. \\ Universitas Islam Negeri Walisongo \\ Email:nurse_afganisme@yahoo.com
}

\begin{abstract}
This study explains efforts for street children to obtain Islamic Education. Islam as a way of life gives a thorough attention to the growth and development of children physical and psychological aspects. The problem is, the majority of street children are neglected in the field of education because of dropping out of school in the productive age. The existence and activation of Islamic boarding schools, NGOs, and even educational volunteers have not been maximized. One sample, according to Social Rehabilitation Section Data, Malang City Social Service, total number of children in 2014 is still 548 children.
\end{abstract}

This study is a type of library research, through qualitative descriptive approach with data collection method of documentation study. Specifically, according to the results of the study, humanist, dialogical, reflective, expressive, and basic needs fulfillment approach is suitable. The form of modeling ("uswatun khasanah") with parenting pattern can give impact. This research suggestion, Islamic education can be done through formal form, nonformal, and informal. Pondok Pesantren, shelter houses, and mosques can be a means, including cooperation among Non Government Associations (NGO's). At the end of the analysis, the researcher suggests that there is early psychological diagnosis and procurement of exclusive kiddos / kindergartens

Keywords: Islamic education, street children, Islamic psychology

\begin{abstract}
Abstrak
Penelitian ini menjelaskan upaya bagi anak jalanan untuk memperoleh Pendidikan Islam. Islam sebagai way of life memberikan perhatian menyeluruh pada sisi pertumbuhan dan perkembangan aspek fisik dan psikis anak. Permasalahannya, mayoritas anak jalanan terbengkelai di bidang pendidikan lantaran putus sekolah di usia produktif. Keberadaan dan aktivasi pondok pesantren, LSM, bahkan volunter pendidikan pun belum maksimal. Satu sampel, menurut Data Seksi Rehabilitasi Sosial, Dinas Sosial Kota Malang, total anjal tahun 2014 masih sejumlah 548 anak.

Studi ini berjenis library research, melalui pendekatan deskriptif kualitatif dengan metode pengumpulan data studi dokumentasi. Secara khusus, menurut hasil penelitian menyebutkan pendekatan humanis, dialogis, reflektif, ekspresif, dan adanya pemenuhan kebutuhan dasar cukup cocok digunakan. Bentuk permodelan (uswatun khasanah) dengan pola pengasuhan mampu memberikan dampak. Saran penelitian ini, Pendidikan Islam bisa dilakukan melalui bentuk formal, nonformal, dan informal. Pondok pesantren, rumah singgah, dan masjid bisa menjadi sarana, termasuk kerjasama antar Non Government Associations (NGO's). Di akhir analisis, peneliti menyarankan adaya diagnosa psikologi dini dan pengadaan Paud/Taman KanakKanak Eksklusif.
\end{abstract}

Kata Kunci: pendidikan Islam, anak jalanan, psikologi Islam. 


\section{A. PENDAHULUAN}

Masalah anak anak jalanan merupakan fenomena global. Menurut UNICEF hal inilah yang menjadi masalah yang tak terhitung bagi jutaan anak di seluruh belahan dunia. ${ }^{1}$ Mereka hidup dengan gaya yang serba fana, dengan kekurangan kebutuhan dasar, seperti makanan, perawatan kesehatan, pendidikan, bahkan tempat, dan rasa aman. Menurut Departemen Sosial RI $1991^{2}$, munculnya anak jalanan karena rendahnya pendapatan keluarga, diharmonis keluarga, rendahnya pendidikan orang tua, keluarga urban yang tidak memperoleh sumber ekonomi, dan persepsi yang keliru orang tua tentang kedudukan anak.

Beberapa penelitian, menyebutkan bahwa mayoritas anak jalanan adalah mereka yang berusia produktif belajar antara 5-17 ataupun antara 9-17 tahun. Penelitian Cumming menyatakan 45\% anak jalanan adalah mereka yang berusia 11-15 tahun. ${ }^{3}$ Hampir senada dengan Kebede dalam penelitiannya di Hawassa City, sekitar $50 \%$ anak jalanan berusia 12-14 tahun. ${ }^{4}$ Ironisnya di Indonesia, dalam penelitian Muslimin di Kota Makassar tahun 2013 mayoritas anak jalanan adalah beragama Islam dan hampir semuanya memiliki pengetahuan ke-Islaman yang teramat minim, termasuk dalam hal pengamalan ibadah. ${ }^{5}$

Tidak hanya itu, Amerika yang dianggap negara demokrasi pertama di dunia dengan Declaration of Independence tahun 1776, hingga saat ini masih mengalami diskriminasi terselubung. Undang undang pendidikan terkenal tahun 2000 "No Child Left Behind" telah lahir dikarenakan masih banyaknya anak yang belum memperoleh

${ }^{1}$ Prince A Cumming, Factors Related to the Street Children Phenomenon in Major Town in Sierra Leone: Comparative Study of the City's Street Children and Children in Normal Family Home (St. Clements Uviversity, t.t), h. 4, www.stclements.edu.

2 Fickar Aksatama, "Pendidikan Luar Sekolah dalam Kerangka Pembinaan Anak Jalanan," PLS-UM Fendikplsum, t.t., www.imadiklus.com.

3 Prince A Cumming, Factors Related to the Street Children Phenomenon in Major Town in Sierra Leone: Comparative Study of the City's Street Children and Children in Normal Family Home, h. 134.

4 Shimelis Kassa Kebede, "The Situation of Street Children in Urban Centers of Ethiopia and the Role of NGOs in Addressing their Socio-Economic Problem: The Case of Hawassa City," International journal Academic Research in Education and Review, 3(3) (April 2015): h. 51.

${ }^{5}$ Abdul Aziz Muslimin, "Peranan Pendidikan Islam bagi Komunitas Anak Jalanan di Kota Makassar," Peranan Pendidikan Islam bagi Komunitas Anak Jalanan di Kota Makassar, 2013, www.azizmuslimi.blogspot.co.id. 
pendidikan. Termasuk banyaknya anak yang masih tersisihkan, tidak berada pada jalur kebudayaan mayoritas (WASP, White Anglo Saxon Protestant). ${ }^{6}$

Permasalahan di atas timbul karena masih ada anggapan bahwa pendidikan bukanlah kebutuhan dasar. Secara kodrati anak memerlukan pendidikan dan bimbingan dari orang dewasa. Namun justru realita yang terjadi adalah dorongan anak terjun ke jalanan dipicu 30\% karena kemiskinan keluarga, 20\% karena kehilangan pengakuan dari keluarga, dan 13,5 \% karena kekacuan keluarga. ${ }^{7}$

Dengan demikian, penyebab anak terjun ke jalanan bukan saja atas permasalahan kebutuhan dasar, pangan ataupun ekonomi semata. Melainkan sudah sampai pada permasalahan psikis dan mental dalam diri anak. Hal ini mengakibatkan mereka memiliki sifat rendah budi pekerti, bodoh, tidak mengakui adanya Tuhan, bahkan mengkhianati-Nya

\section{B. KAJIAN TEORI}

\section{Konsep Anak Jalanan}

Anak jalanan adalah anak yang sebagian besar waktunya berada di jalanan atau tempat-tempat umum. Mereka biasanya memiliki ciri-ciri sebagai berikut: usia di antara 5 sampai 18 tahun, pakaian kusam, tidak terurus, serta memiliki mobilitas yang tinggi. ${ }^{8}$ Anak jalanan sering disebut juga dengan Anak 505, sebagaimana sering diambil dari Kitab Undang-Undang Hukum Pidana (KUHP) untuk nomor pasal yang sering

${ }^{6}$ H.A.R. Tilaar, Perubahan Sosial dan Pendidikan: Pengantar Pedagogik Transformatif untuk Indonesia (Jakarta: Rineka Cipta, 2012), h. 311.

7 Shimelis Kassa Kebede, "The Situation of Street Children in Urban Centers of Ethiopia and the Role of NGOs in Addressing their Socio-Economic Problem: The Case of Hawassa City," International Journal Academic Research in Education and Review (IJABER), April 2015,Vol. 3(3), pp. 45-57, diakses tanggal 17 Oktober 2015, dari www.academicresearchjournals.org., h. 51.

8 "Senada menurut Tata Sudrajat sebagaimana dikutip oleh Turah Asih Lestari (2013: 17), dikategorikan sebagai anak jalanan jika memenuhi kriteria sebagai berikut: "(a) usia berkisar antara 6 sampai 18 tahun; (b) intensitas hubungan dengan keluarga; (c) waktu yang dihabiskan di jalanan lebih dari 4 jam setiap hari; (d) masih berhubungan secara teratur minimal bertemu sekali setiap hari; (e) frekuensi berkomunikasi dengan keluarga sangat minim maksimal satu kali dalam seminggu; (f) sama sekali tidak ada komunikasi." 
digunakan dasar pegangan. Untuk lebih menghaluskan, anak jalanan juga disebut juga anak mandiri. ${ }^{9}$

Kegiatan yang dilakukan anak jalanan sebagian besar menggunakan jalan sebagai tempat tinggal dan hidup, tempat bermain, dan berjualan. Sumber pendapatan uang dilakukan dengan cara meminta-minta, berjualan, serta mengamen. Menurut Tata Sudrajat selain yang termaksud di atas, aktivitas anak jalanan sebagaimana berikut: menyemir sepatu, menjadi calo, mengelap mobil, mencuci kendaraan, menjadi pemulung, pengamen, menjadi kuli angkut, menyewakan payung, serta menjadi penghubung/ penjual jasa. ${ }^{10}$

Berikut kriteria umum yang anak jalanan menurut petunjuk teknis Pembinaan Kesejahteraan Sosial Anak Jalanan melalui program Health and Nutrion Sector Development Programme (HNSDP):

1) Children of the street (anak yang hidup di jalanan), yaitu anak yang sudah putus dengan orang tuanya dan tidak sekolah maupun masih sekolah. 2) Children on the street (anak yang bekerja di jalanan), yaitu anak-anak yang berhubungan tidak teratur dengan orangtuanya dan sudah tidak bersekolah maupun masih sekolah. 3) Vulnerable to the street children (anak yang rentan menjadi anak jalanan), yaitu anak yang masih tinggal dengan orangtuanya, namun sudah mencari nafkah di jalan dan umumnya masih sekolah. ${ }^{11}$

Lebih spesifik lagi, kriteria dan ciri-ciri sebagai anak jalanan tertuang dalam kriteria Departemen Sosial RI 1999.

Hingga kini ada beberapa lembaga sosial yang menangani kasus tersebut, misalnya Kapas di Solo, Satu Atap di Semarang, Yayasan Diponegoro di Yogyakarta, Asian Child Protection Helpline, MUSLIM Youth Helpline, Childline, dan Iranian and Kurdish Woman's Rights Organization (IKWRO). IKWRO adalah organisasi sekuler besar

9 Syaifuddin Zuhri, "Peran Keluarga dalam Pendidikan Akhlak Anak Jalanan: Studi Kasus Anak Jalanan di Kawasan Tugu muda Semarang" (Fakultas Tarbiyah, Institut Agama Islam Negeri Walisongo, 2011), h. 8, www.library.walisongo.ac.id.

10 Turah Asih Lestari, "Pelaksanaan Pendidikan Karakter bagi Anak Jalanan dan Implikasinya terhadap Pendidikan Islam" (Yogyakarta: UIN Sunan Kalijaga, 2013), h. 18.

${ }^{11}$ Abdul Aziz Muslimin. Peranan Pendidikan Islam Bagi Komunitas Anak Jalanan di Kota Makassar. Ibid. 
dimana klien mereka adalah Muslim. Klien IKWRO adalah mereka yang memerlukan bantuan tentang masalah hukum keluarga, seperti tempat tinggal anak dan perceraian. ${ }^{12}$ Lembaga-lembaga ini didirikan dengan maksud mencegah intervensi negara terutama perlindungan perempuan dan anak-anak. Selain itu juga menciptakan sistem sosial dan hukum yang terpisah di bawah wewenang pemimpin yang ingin memaksakan otoritas agama dan budaya dalam masyarakat minoritas. ${ }^{13}$

\section{Perspektif Islam terhadap eksistensi Anak Jalanan}

Perspektif Islam terhadap anak jalanan tentu tak terlepas dari nilai fundamental Al-Quran dan Sunnah. Quran surah Al-Baqarah (2: 83) disebutkan akan anjuran untuk berbuat baik kepada ibu, bapak, kaum kerabat, anak-anak yatim, dan orang-orang miskin. Sebagian anak jalanan tersebut tentunya ada yang berasal dari golongan yatim dan miskin, namun tidak semua anak yatim dan miskin tersebut adalah anak jalanan sebagaimana saat ini. Anak jalanan yang tugasnya meminta-minta, terkadang masih memiliki orang tua. Dengan demikian, aksi jalanan ini merupakan mata pencaharian mereka. Perlakuan seperti itu tentunya tidak dibenarkan oleh agama, dimana orang tua menelantarkan anaknya. ${ }^{14}$

Di sisi lain, pada surah Al-Baqarah (2: 177) dijelaskan, firman-Nya.

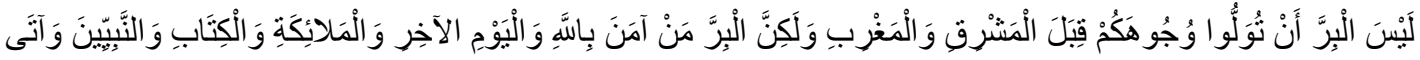

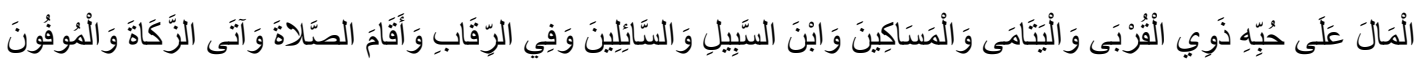

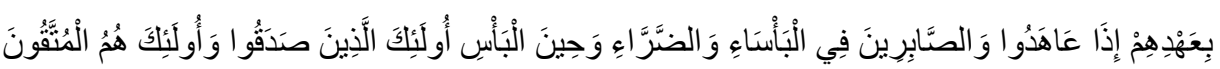

Kebajikan ialah beriman kepada Allah, hari akhir, malaikat-malaikat, kitabkitab, nabi-nabi, dan memberikan harta yang dicintainya kepada anak-anak yatim, orang-orang miskin, musafir, orang yang meminta-minta, memerdekakan hamba sahaya, mendirikan shalat, menunaikan zakat, menepati janji bila berjanji, bersabar dalam kesempitan, penderitaan, dan dalam peperangan. Keseluruhan golongan

12 Fionnuala Murphy, "Sharia Law in the UK: Compromising Woman and Children's Safety," Multicultural and Child Protection in Britain: Sharia Law and Other Failures, (London: One Law for All, 2013) Vol. 20-31, diakses tanggal 3 Maret 2016, dari www.onelawforall.org.uk., h. 20.

${ }^{13}$ Maryam Namazie, "Child Veiling", Multicultural and Child Protection in Britain: Sharia Law and Other Failures, vol. 32-34 (London: One Law for All, 2013), h. 42, www.onelawforall.org.uk.

${ }^{14}$ Kurniadi El-Kamal, "Pandangan Agama Islam tentang Anak Jalanan," 2010, www.perspektif25.blogspot.co.id. 
tersebut adalah orang yang dianggap beriman dan bertakwa. Tafsir Departemen Agama RI, menyebutkan bahwa Iman harus ditandai dengan amal perbuatan yang nyata, di antaranya:

Memberikan bantuan harta kepada anak-anak yatim dan orang-orang yang tidak berdaya. Mereka membutuhkan pertolongan dan bantuan untuk menyambung hidup dan meneruskan pendidikannya, sehingga mereka bisa hidup tentram sebagaim manusia yang bermanfaat dalam lingkungan masyarakatnya.... Memberikan harta kepada orang yang terpaksa memintaminta karena tidak ada jalan lain baginya untuk menutupi kebutuhan. ${ }^{15}$

Sementara itu, dalam Tafsir Al-Misbah terkait ayat tersebut menerangkan bahwa meskipun sisi keimanan hakikatnya tidak tampak, namun ayat tersebut memberikan penjelasan contoh-contoh sisi kebajikan sempurna dari yang lahir ke permukaan. Contoh terkait anak jalanan ini adalah, bersedia mengorbankan kepentingan pribadi demi orang lain dengan cara yang tulus demi meraih cinta-Nya, di antaranya kepada orang yang meminta-minta. ${ }^{16}$ Dengan demikian, anak jalanan tergolong orang yang meminta-minta, maka kita pun dianjurkan untuk menyantuninya. ${ }^{17}$

Quraish Shihab menjelaskan, secara umum di dalam Al-Quran semua ayat-ayat yang turun pada periode Mekkah adalah tuntutan untuk memerhatikan sisi kejiwaan dan akhlak anak yatim. ${ }^{18}$ Indikasinya tuntunan pertama bantuan yang harus diserahkan kepada mereka adalah memelihara agar tidak terlantar, terabaikan dan terganggu kejiwaannya. Dengan demikian, tidak ada alasan bagi seseorang yang memiliki ekonomi lemah pun untuk tidak memberikan perhatiannya kepada anak yatim maupun kaum lemah, karena Allah bukan secara langsung memerintahkan pemberian materi, melainkan pemberian perhatian bagi perkembangan jiwa mereka ke arah positif.

${ }^{15}$ Kementerian Agama RI, Tafsir Al-Quran (Jakarta, 2010), h. 248 et. seq.

${ }^{16}$ M. Quraish Shihab, Tafsir Al-Mishbah (Jakarta: Lentera Hati, 2011), h. 468 et. seq.

17 Kurniadi El-Kamal, "Pandangan Agama Islam tentang Anak Jalanan,"loc. cit_

${ }^{18}$ M. Quraish Shihab, Membumikan Al-Quran Jilid 2 (Jakarta: Lentera Hati, 2011), h. 184. 


\section{Teori Pendidikan Anak Jalanan secara Universal}

Anak jalanan dalam kasus ini tergolong sebagai anak yang berkebutuhan khusus. Maka pola penerapannya adalah jenis pendidikan yang inklusif. Prinsip pendidikan inklusif di adopsi dari Konferensi Salamca tentang Pendidikan Kebutuhan Khusus, UNESCO, tahun 1994 dan di ulang kembali pada Forum Pendidikan Dunia di Dakar tahun 2000.

Pendidikan inklusif mempunyai arti bahwa sekolah harus mengakomodasi semua anak tanpa mempedulikan keadaan fisik, intelektual, sosial, emosi, bahasa, atau kondisi-kondisi lain, termasuk anak-anak penyandang cacat anak-anak berbakat (gifted children), pekerja anak dan anak jalanan, anak di daerah terpencil, anak-anak dari kelompok etnik dan bahasa minoritas dan anak-anak serta anak-anak yang tidak beruntung dan terpinggirkan dari kelompok masyarakat.

\section{HASIL PENELITIAN DAN PEMBAHASAN}

\section{Upaya Pendidikan bagi Anak Jalanan}

Pengertian upaya bagi anak jalanan yakni proses, cara, atau tindakan yang efektif dan efisien bagi anak jalanan untuk memperoleh pelayaan lebih baik, dalam studi ini Pendidikan Islam. Pendidikan Islam dikembangkan dan dipahami dari sumber dasarnya dan nilai-nilai fundamental yang terkandung di dalam Al-Quran dan Sunnah. Dalam pengertian ini, pendidikan Islam dapat berwujud pemikiran maupun teori pendidikan yang berdasar serta dikembangkan pada kedua sumber dasar tersebut. Pada dasarnya menurut Sobhi Rayan dalam tulisannya "Islamic Philosophy of Education" menyebutkan,

Islamic education encourages critical thinking as a research method for development of knowledge and science, but science in itself has a functional role to make human life better, this science constitutes on ethical dimension. Therefore, thinking is considered a duty in the Islamic view, because thinking is a tool for progress life that conditioned in achieving values in the reality. ${ }^{19}$

19 Sobhi Rayan, "Islamic Philosophy of Education", International Journal of Humanities and Soccial Science, vol. Vol.2, 19 (Israel: Department of Education, Alqasemi Academy Collage, 2012), www.ijhssnet.com. 
Pendidikan Islam difungsikan untuk mendorong pemikiran kritis sebagai metode penelitian pengembangan ilmu pengetahuan dan ilmu. Namun demikian, ilmu pengetahuan tersebut memiliki peran fungsional untuk membuat hidup manusia lebih baik, termasuk dalam dimensi etika. Dengan demikian, maka pemikiran para tokoh, terutama tokoh-tokoh Islam sangat diperhitungkan bagi kemajuan hidup, termasuk pendidikan Islam. Artinya, pendidikan Islam merupakan proses pembudayaan dan pewarisan ajaran agama, budaya, dan peradaban umat Islam dari generasi ke generasi.

Berikut data hasil penelitian. Pertama, penelitian Turah Asih Lestari berjudul “Pelaksanaan Pendidikan Karakter bagi Anak Jalanan dan Implikasinya terhadap Pendidikan Agama Islam", studi kasus di Rumah Singgah dan Belajar Diponegoro. Hasil penelitian menunjukkan. (1) Muatan materi yang ditanamkan berupa kejujuran, kemandirian, sopan santun, dan beberapa nilai karakter lainnya. (2) Pembimbingan dalam karakter dilaksanakan seminggu sekali untuk anak out house, dan untuk anak in house diberi jadwal harian dari bangun tidur hingga tidur lagi. (3) Implikasi terhadap pendidikan Islam, terdapat dua cara untuk mendidik mereka, yakni menggunakan strategi writing in the here dan learn from your experience. ${ }^{20}$

Kedua, hasil penelitian oleh Siti Mujaiah dari Universitas Islam Negeri Sunan Kalijaga Yogyakarta. Hasil penelitian dengan judul "Pendekatan Humanis dalam Pembinaan Agama Islam bagi Anak Jalanan" yakni (1) pendekatan yang cocok digunakan untuk pembinaan anak jalanan adalah bercorak humanis, berupa prinsip dialogis, reflektif ekspresif. (2) Adanya pemenuhan kebutuhan dasar anak dampingan sebagaimana teori Abraham Moslow. ${ }^{21}$

Ketiga, hasil penelitian disertasi oleh Prince A. Cummings di Sierra Leone, perilaku dan cara hidup anak jalanan mengadopsi dari orang lain yang ada di sekitar mereka sebagai model. Maka, bentuk pembinaan dengan permodelan yang baik sangat

${ }^{20}$ Turah Asih Lestari, "Pelaksanaan Pendidikan Karakter bagi Anak Jalanan dan Implikasinya terhadap Pendidikan Islam", h. 91 et. seq.

${ }^{21}$ Mujaiah, Siti, Pendekatan Humanis dalam Pembinaan Agama Islam bagi Anak Jalanan, (Yogyakarta: Universitas Islam Negeri Yogyakarta, 2013), h. 107. 
diperlukan. Berdasar hal itu, menurut Garmezy mengungkapkan bahwa perbaikan melalui pengasuhan pun cukup baik diperlukan.22

Berdasar pada beberapa penelitian tersebut, maka bentuk dari upaya yang dapat penulis simpulkan adalah pendidikan dengan pendekatan humanis, berupa prinsip dialogis, reflektif ekspresif, pembentukan kepercayaan akan rasa aman, adanya langkah modelling ${ }^{23}$ (uswatun khasanah) dan adanya pemenuhan kebutuhan dasar mereka. Untuk metodenya bisa menggunakan metode pembelajaran writing in the here dan learn from your experience yang sesuai karakter mereka dengan pemberian susunan jadwal harian yang tepat.

Upaya dan program khusus pada anak jalanan bisa dilakukan melalui berbagai program, sebagaimana program lain yang digunakan untuk anak-anak pada umumnya. Namun demikian, karena lingkup dan permasalahan yang berbeda, maka program khusus bagi anak jalanan pun sangat diperlukan. Hakikatnya keberlangsungan pendidikan Islam bukanlah terletak pada keberadaan program itu, melainkan keberadaan usaha pendidikan yang seumur hidup.

Menurut Umar Shihab seseorang (anak didik) haruslah berusaha maksimal untuk meraih sesuatu. Indikasinya seseorang dituntut untuk terus menerus belajar. ${ }^{24}$ Misi pendidikannya adalah mendorong mereka untuk belajar terus menerus, mandiri dalam memperoleh ilmu pengetahuan dengan atau tanpa bimbingan guru. Oleh karena itu, berikut beberapa lembaga pendidikan khusus yang bisa dijadikan alternatif bagi anak jalanan untuk memperoleh pendidikan Islam.

22 Prince A Cumming, Factors Related to the Street Children Phenomenon in Major Town in Sierra Leone: Comparative Study of the City's Street Children and Children in Normal Family Homes, h. 82

23 “Dalam proses permodelan (modelling) memerlukan adanya konsistensi. Hal ini akan berakibat pada pembentukan persepsi. Jika persepsi kurang baik, maka hasil dari pendekatan permodelan pun akan turut memberikan pengaruh. Menurut De Vito terdapat enam proses yang memengaruhi persepsi, yakni: teori kepribadian implisit, ramalan yang dipenuhi sendiri, aksentuasi perseptual, primasi-resensi, konsistensi, dan stereotip, (Alex Sobur, Psikologi Umum dalam Lintasan Sejarah, cetakan II, [Bandung: Pustaka Setia, 2009], h. 455.).

${ }^{24}$ Umar Shihab, Kontekstualitas Al-Quran: Kajian Tematik atas Ayat-Ayat Hukum dalam Al-Quran (Jakarta: Penamadani, 2005), h. 168. 


\section{a. Rumah Singgah sebagai lembaga pendidikan nonformal}

Rumah singgah menurut Sudrajat didefinisikan sebagai wahana perantara yang menghubungkan antara anak jalanan dengan pihak-pihak pembantu mereka. ${ }^{25}$ Rumah singgah juga bisa dijadikan tempat penyampaian pendidikan Islam nonformal. Mereka bisa bersosialisasi dengan sesamanya sesuai norma yang berlaku.

Fungsi rumah singgah tersebut secara umum: (1) Dapat menjadi meeting point (tempat pertemuan antara pekerja sosial, pendidik Islam dengan anak jalanan). (2) Pusat assessment dan rujukan; (3) Perlindungan (tempat berlindung dari kekerasan yang terjadi di jalanan); (4) Pusat informasi (menyediakan informasi berbagi hal yang berkaitan dengan kepentingan anak). ${ }^{26}$ Melalui upaya pengadaan rumah singgah anak jalanan akan semakin mudah mengakses pendidikan agama Islam. Hal ini tentu sangat tergantung pada manajemen dan visi misi rumah singgah tersebut.

\section{b. Pesantren bagi anak jalanan}

Pesantren khusus adalah solusi terbaik dalam memberikan pendidikan berkesinambungan dengan pola asrama. Pola seperti ini cukup menarik dan dianggap sebagai solusi terbaik karena bentuk pendidikannya berkesinambungan. ${ }^{27}$ Munurut Choirul Fuad Yusuf dalam masa jabatannya sebagai Direktur Pendidikan Diniyah dan Pondok Pesantren, sebagaimana dilansir pada media cetak Ikhlas Beramal, ${ }^{28}$ model pembelajaran dari pondok pesantren ini bisa berupa pengintegrasian antara pendidikan agama, pendidikan umum, dan keterampilan kerja (vocational skill). Hal ini mengindikasikan bahwa pendidikan Islam yang tersajikan tidak bisa berdiri sendiri melainkan harus saling menjalin komunikasi dengan pendidikan lainnya. Jika dikombinasikan antara esensi pendidikan Islam dan pesantren, keduanya akan saling memberikan hubungan yang mutualis bahkan bisa terjadi pembinaan intensif.

${ }^{25}$ Turah Asih Lestari, "Pelaksanaan Pendidikan Karakter bagi Anak Jalanan dan Implikasinya terhadap Pendidikan Islam," h. 18.

26 Ibid., h. 19.

27 "Sebenarnya bukan hanya anak jalanan saja yang menjadi kajian kritis dalam upaya peningkatan mutu pendidikan Islam. Melainkan pada kelompok anak marjinal lainnya seperti anak terlantar, anak-anak yang tertinggal di daerah korban bencana, mereka yang terisolir, dan anak dari keluarga sangat miskin.

${ }^{28}$ Ikhlas Beramal (media berita), Pesantren Bagi Anak Jalanan, Nomor 62 Tahun XIII April 2010, diunduh tanggal 5 November 2015, dari www.kemenag.go.id., h. 49. 


\section{Analisa dengan pendekatan psikologi}

Menurut hasil penelitian Cummings dari beberapa studi, meskipun anak jalanan relatif memiliki perilaku ekstrem dan masalah emosional, namun gejala tersebut sulit diidentifikasi oleh gangguan kejiwaan umumnya. Penyebabnya karena mereka tidak menyadari dan tidak pernah timbul kesadaran untuk mencari pertolongan. Berikut kemungkinan-kemungkinan yang sering terjadi pada anak jalanan: Pertama, masalah traumatis. Berkaitan masalah traumatis anak jalanan sebab perilaku non-manusiawi yang mereka rasakan selama di jalanan, tentulah tidak mudah bagi kita untuk menghapuskannya. Justru, trauma yang mereka alami bisa saja menjalar ke usia dewasa. ${ }^{29}$

Kedua, masalah motivasi anak jalanan. Motivasi mereka untuk beribadah dan konsisten menjalankan agamanya masih cukup rendah. Hal ini mengindikasikan bahwa fitrah mereka untuk menjalankan ibadah kepada Tuhannya mulai luntur. Sebab itu, fungsi lingkungan harus segera dikembalikan pada lingkungan kondusif. Namun demikian, meskipun pada dasarnya pembentukan kebiasaan, kepribadian, dan nilainilai pada anak jalanan ini disebabkan oleh faktor lingkungan, bukan berarti lingkungan negatif akan selalu menghasilkan reaksi negatif. Henry E. Garret menyatakan bahwa pembawaan dan lingkungan memiliki hubungan yang saling membutuhkan, bukan saling bertentangan. ${ }^{30}$ Kenyataannya, lingkungan yang mereka tempati tidaklah baik untuk pertumbuhan perkembangan psikologis. Termasuk juga adanya rasa minimnya pengakuan, hilangnya rasa kepercayaan, dan rasa keamanan. Berdasar hal tersebut, menurut Garmezy mengungkapkan bahwa perbaikan melalui pengasuhan pun cukup baik diperlukan bagi mereka.

Ketiga, masalah kebutuhan pokok. Pendidikan Islam juga memerhatikan, aspek fisik, mental emosional, mental sosial, maupun mental spiritual dan segala aspek pembentuk kepribadian dari masa kanak-kanak hingga dewasa, bahkan pada masa

29 Prince A Cumming, Factors Related to the Street Children Phenomenon in Major Town in Sierra Leone: Comparative Study of the City's Street Children and Children in Normal Family Homes. (Menurut hemat penulis, upaya pendidikan Islam ini harus secara maksimal didiagnosa sedetail mungkin. Termasuk diagnosa dari sudut pandang psikologi, ekonomi, dan sosial.)

30 Zakiah Daradjat, Metodik Khusus Pengajaran Agama Islam, (Jakarta: Bumi Aksara, 2004), h. 128. 
prenatal (masa dalam kandungan). Pendidikan Islam menurut Pia Karlsson and Amir Mansory ${ }^{31}$ harus memenuhi segala aspek pengembangan yang berupa spiritual, intelektual, imajinatif, fisik, ilmiah, linguistik, baik itu secara individual, maupun kolektif. Dengan demikian, sebenarnya tugas pendidikan Islam ini sangatlah berat.

Pembahasan kali ini, penulis menganalisis rendahnya motivasi anak jalanan dalam menjalankan agamanya menggunakan pendekatan sudut pandang Maslow's Need Hierarchy Theory/ A theory of Human Motivation (1943). Berikut rinciannya, tersaji dalam Gambar 2.1

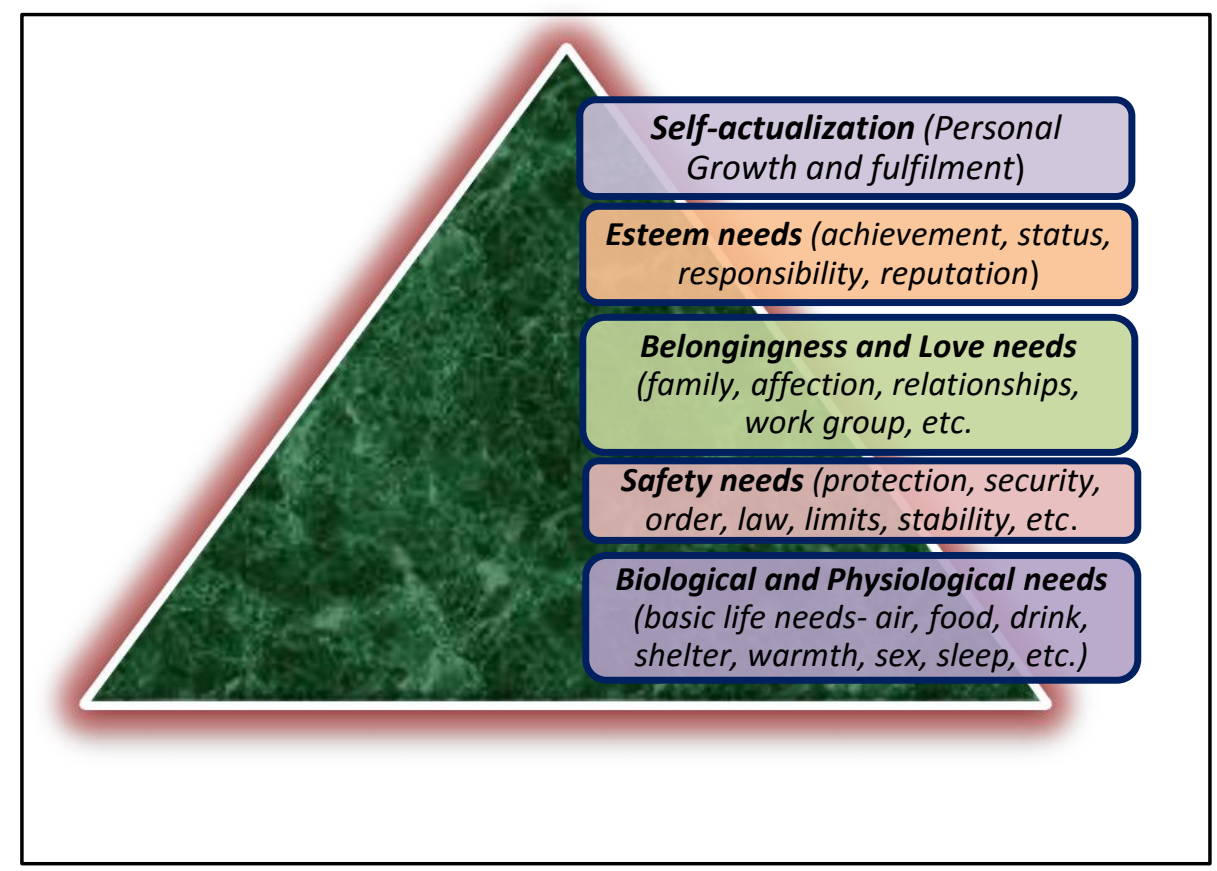

Teori Moslow menjelaskan bahwa kebutuhan seseorang berjenjang. Jika satu kebutuhan pertama terpenuhi, kebutuhan kedua akan muncul sebagai kebutuhan pertama. Selanjutnya, jika kebutuhan tingkat kedua terpenuhi, maka akan muncul kebutuhan ketiga dan seterusnya. Namun sayangnya, anak jalanan merasa masih dalam taraf awal, dimana kebutuhan pertama/ physiological needs (kebutuhan untuk mempertahankan hidup) masih menjadi prioritas, sehingga motivasi memenuhi hajat pendidikan pun masih dalam kategori prioritas sampingan. Kondisi tersebut memang

31 Pia Karlsson dan Amir Mansory, An Afghan Dilemma: Education, Gender and Globalisation in an Islamic Context (Swedia: Institute of International Education, Department of Education Stockholm University, 2007), h. 49. 
benar adanya, dimana motivasi psikologi sebagai fitrah dan menjadi tabiat bawaan manusia sejak dilahirkan. Berikut kategorinya:

1) Motivasi menjaga kelangsungan hidup dengan pemenuhan kebutuhan seperti lapar, haus, lelah, kepanasan, kedinginan, sakit, dan bernafas.

2) Motivasi menjaga kelestarian jenis. ${ }^{32}$

Sebagai langkah awal, pendidik harus memerhatikan aspek belongingness and love need (affiliation or acceptance needs) tergambar pada hieraki kebutuhan Maslow, berupa kebutuhan akan sosial, teman, dicintai, dan mencintai, serta diterima kelompok masyarakat. ${ }^{33}$ Namun, sayangnya mayoritas anak jalanan tidak memiliki hubungan baik dengan keluarga, sehingga kurang stabil dan lebih sering bergantung dengan kehidupan di jalanannya.

Menurut Maslow, satu kebutuhan pertama telah terpenuhi, kebutuhan kedua akan muncul sebagai kebutuhan yang pertama. Dengan demikian, kebutuhan ini bertingkat dan memiliki kedudukan yang berbeda. Hampir senada, jika dilihat dari sudut pandang Islam bahwa manusia juga memerlukan motivasi kejiwaan maupun motivasi spiritual. Namun dalam sudut pandang ini, ia tidak berhubungan langsung dengan kebutuhan manusia secara biologis. ${ }^{34}$ Dengan demikian, menurut hemat penulis, posisi kedudukan motivasi kejiwaan maupun spiritual yang salah satunya bisa diraih melalui pendidikan Islam tersebut tetap harus terpenuhi meskipun kebutuhan secara psikologi belum terpenuhi. Atau keduanya memiliki kedudukan yang sederajat, sama pentingnya antara: (1) motivasi utama (motivasi psikologi) dan (2) motivasi kejiwaan dan motivasi spiritual. Islam juga meletakkan batasan-batasan tertentu bagi umatnya untuk memenuhi kebutuhanya. ${ }^{35}$ Pertama, pemenuhan kebutuhan motivasi dengan jalan yang halal saja dengan menjauhi pemenuhannya

32 Musfir bin Said Az-Zahrani, Konseling Terapi, diterjemahkan oleh Sari Narulita dan Miftahul Jannah, dari At-taujiih wal Irsyaadun Nafsi Minal Qur'aanil Karim was-Sunnatin Nabawiyyah, (Jakarta: Gema Insani, 2005).

${ }_{33}$ Malayu S. P. Hasibuan, Manajemen Sumber Daya Manusia, cetakan ke-12 (Jakarta: Bumi Aksara, 2009), h. 155.

${ }^{34}$ Musfir bin Said Az-Zahrani, Konseling Terapi, h. 118.

35 Ibid., h. 141. 
pada jalan yang diharamkan. Kedua, adanya keseimbangan dalam pemenuhan kebutuhan. ${ }^{36}$

Dari data tersebut dan rumusan beberapa teori tentang pendidikan Islam, diperoleh gambaran bahwa pendidikan Islam terlebih pada anak jalanan harus segera diupayakan pada usia dini. Berikut Gambar 2.2. penulis gambarkan pendidikan Islam anak jalanan dengan analogi Sayap Кири-Кири:

Gambar 2.2. Konsep upaya bagi anak jalanan untuk memperoleh Pendidikan Islam

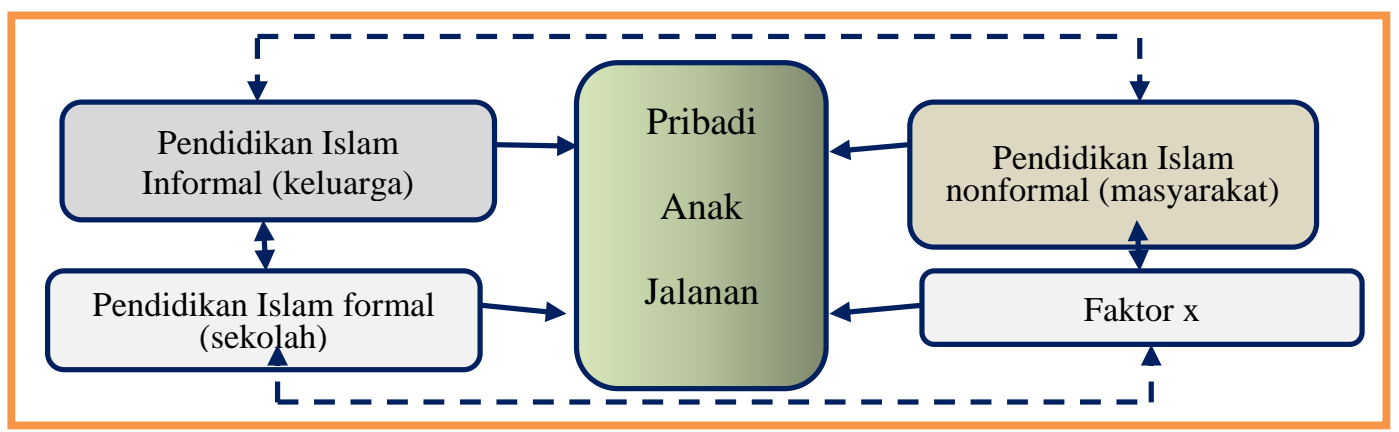

Analogi tersebut, mengisyaratkan jika satu bagan rusak, maka baik secara langsung ataupun tidak, akan memengaruhi kinerja bagan lainnya. Termasuk pengaruhnya langsung pada pribadi anak jalanan. Pendidikan Islam khususnya bagi anak jalanan ini adalah sesuatu yang sangat komplek, karena objek kajiannya adalah manusia. Namun demikian, segala bentuk pendidikan Islam yang diupayakan pada mereka tetap akan memiliki dampak. Akan tetapi dampak tersebut tergantung dari besar kecilnya respon penerimaan dan penolakannya.

Sebagai penyeimbang, maka harus ada dukungan dari faktor lain yang menjadi support power. Di antaranya, pendidikan Islam lembaga nonformal (masyarakat). Berbagai kepincangan dari akses pendidikan agama pada keluarga dan pada pendidikan formal mendorong salah satu lembaga yang memiliki peran besar dalam kasus pendidikan agama Islam ini adalah lembaga nonformal dari masyarakat. Masyarakat bisa memecah tugasnya dengan berbagai kebijakan. 1) Menjadi keluarga angkat. Hal ini

36 "Islam melarang adanya berlebih-lebihan maupun melebihi batas normal yang telah ditetapkan Syariat. Masyarakat jalanan, termasuk anak-anak jalanan memenuhi kebutuhan motivasi dengan jalan yang tidak baik. Di sinilah sebenarnya tugas pendidikan Islam bagi anak jalanan untuk segera melakukan tindakan nyata memutus degradasi moral yang terjadi pada mereka. 
akan memerankan fungsi pengganti dari keluarga anak jalanan. 2) Mendirikan pendidikan Islam khusus anak jalanan. Melalui pendidikan di pondok pesantren ataupun rumah singgah. 3) Pengaktifan volunter-volunter pendidikan, misalnya dari NGOs ataupun lembaga formal Islam melalui program Kuliah Kerja Nyata (KKN).

Faktor x (internal dan eksternal), berasal dari dalam peserta didik maupun dari luar. Unsur luar di antaranya lingkungan alami dan lingkungan sosial. Misalnya, cuaca, suhu, kondisi wilayah geografis, kehidupan ekonomi, politik, dan lain sebagainya yang berasal dari luar individu. Sedangkan faktor internal, terdiri dari unsur fisiologi dan psikologis, baik secara jasmani maupun ruhani, bisa berupa faktor pembawaan, maupun faktor kejiwaan. Sedangkan psikologis, terdiri dari minat, kecerdasan, bakat, motivasi, dan kemampuan kognitif. ${ }^{37}$

Berdasar hubungan kausalitas tersebut, masa depan pendidikan Islam anak jalanan sebenarnya sangat tergantung dari uluran tangan masyarakat saat ini, termasuk kebijakan pendidikan. Sebagaimana dikemukakan oleh Tilaar \& Nugroho bahwa kebijakan pendidikan di masa depan akan banyak meminta affirmative action melalui kebijakan publik agar harkat manusia yakni kesamaan hak dan kewajiban manusia dalam masyarakatnya dapat diwujudkan. Maka dari itu, dibutuhkan trust (percaya) dalam kehidupan bermasyarakat. Jika sikap percaya itu hilang, maka sikap mencurigai, tribalisme negatif atau etnosentrisme sampai chauvinisme hidup akan tumbuh dengan pesat. Oleh sebab itu, lembaga pendidikan Islam, pendidik aktivis Islam, dan tak terbatas hingga pemimpin Islam pun hendaknya melebarkan sayapnya hingga menyentuh pendidikan kaum jalanan ini.

\section{SIMPULAN}

Upaya pendidikan Islam bisa dilakukan melalui beberapa cara, di antaranya pendekatan humanis, dialogis, reflektif, dan ekspresif, bisa berwujud dalam pembelajaran writing in the here dan learn from your experience. Konsep strategi uswatun khasanah (modelling) memiliki efek yang cukup efektif dalam upaya pencapaian keberhasilan pendidikan Islam. Di samping itu, berdasar penelitian, perlu adanya pemenuhan kebutuhan dasar serta menyarankan adanya diagnosa psikologi dini bagi 177.

37 Syaiful Bahri Djamarah, Psikologi Pendidikan, II (Jakarta: Rineka Cipta, 2011), h 
mereka. Menurut analisis, penulis menyarankan adanya jenis pendidikan yang berpotensi bisa memberikan dukungan lebih besar pada mereka yang berwujud pendidikan nonformal dari lembaga kemasyarakatan melalui fungsi ganda, misalnya melalui pendidikan berjenis pondok pesantren maupun rumah singgah. Melalui kerjasama antar organisasi, terutama NGOs (Non Goverment Associations) setidaknya pendidikan Islam bagi anak jalanan bisa tersambung kembali.

Selanjutya, salah satu upaya yang penulis sarankan bisa berpotensi memiliki dampak besar jangka panjang, akan lebih baik jika diterapkan Pendidikan Usia Dini maupun Pendidikan Taman Kanak-Kanak Exclusive. Hal ini mengingat banyaknya penelitian bahwa sebagian besar anak jalanan sudah terhenti untuk belajar di usia sekolah. Selanjutnya, upaya pembinaan keagamaan bagi orang tua anak jalanan pun perlu digerakkan kembali, mengaktifkan fungsi masjid di lingkungan mereka, serta upaya dan campur tangan para volunter pendidikan Islam pun akan sangat membantu.

\section{DAFTAR PUSTAKA}

Abdul Aziz Muslimin. "Peranan Pendidikan Islam bagi Komunitas Anak Jalanan di Kota Makassar." Peranan Pendidikan Islam bagi Komunitas Anak Jalanan di Kota Makassar, 2013. www.azizmuslimi.blogspot.co.id.

Aksatama, Fickar, Pendidikan Luar Sekolah dalam Kerangka Pembinaan Anak Jalanan, PLSUM: Fendikplsum, t.t., diakses tanggal 5 November 2015, dari www.imadiklus.com.

Al-Azhar University, Children in Islam: Their Care, Development, and Protection, (summary), International Islamic Center for Population Studies and Research: UNICEF, 2005, diakses tanggal 3 Maret 2016, dari www.google.com.

Az-Zahrani, Musfir bin Said, Konseling Terapi, diterjemahkan oleh Sari Narulita dan Miftahul Jannah, dari At-taujiih wal Irsyaadun Nafsi Minal Qur'aanil Karim wasSunnatin Nabawiyyah, Jakarta: Gema Insani, 2005.

Cumming, Prince A., Factors Related to the Street Children Phenomenon in Major Town in Sierra Leone: Comparative Study of the City's Street Children and Children in Normal Family Homes, St. Clements Uviversity, t.t., diakses tanggal 21 Oktober 2015, dari www.stclements.edu.

Daradjat, Zakiah, Metodik Khusus Pengajaran Agama Islam, Jakarta: Bumi Aksara, 2004.

Djamarah, Syaiful Bahri, Psikologi Pendidikan, Edisi II, Jakarta: Rineka Cipta, 2011. 
El-Kamal, Kurniadi, Pandangan Agama Islam tentang Anak Jalanan, dinduh tanggal 10 Oktober 2015, dari www.perspektif25.blogspot.co.id., 2010.

Fickar Aksatama. "Pendidikan Luar Sekolah dalam Kerangka Pembinaan Anak Jalanan." PLS-UM Fendikplsum, t.t. www.imadiklus.com.

Fionnuala Murphy. "“Sharia Law in the UK: Compromising Woman and Children's Safety," Multicultural and Child Protection in Britain: Sharia Law and Other Failures,." London: One Law for All, Multicultural and Child Protection in Britain: Sharia Law and Other Failures, 20-31 (2013).

H.A.R. Tilaar. Perubahan Sosial dan Pendidikan: Pengantar Pedagogik Transformatif untuk Indonesia. Jakarta: Rineka Cipta, 2012.

Hasibuan, Malayu S. P., Manajemen Sumber Daya Manusia, Jakarta: Bumi Aksara, cetakan ke-12, 2009.

Ikhlas Beramal (media berita), Pesantren Bagi Anak Jalanan, Nomor 62 Tahun XIII April 2010, diunduh tanggal 5 November 2015, dari www.kemenag.go.id.

Karlsson, Pia \& Amir Mansory, An Afghan Dilemma: Education, Gender and Globalisation in an Islamic Context, Swedia: Institute of International Education, Department of Education Stockholm University, 2007.

Kebede, Shimelis Kassa, "The Situation of Street Children in Urban Centers of Ethiopia and the Role of NGOs in Addressing their Socio-Economic Problem: The Case of Hawassa City," International journal Academic Research in Education and Review (IJABER), April 2015, Vol. 3(3), pp. 45-57, diakses tanggal 17 Oktober 2015, dari www.academicresearchjournals.org.

Kementerian Agama RI. Tafsir Al-Quran. Jakarta, 2010.

Kurniadi El-Kamal. “Pandangan Agama Islam tentang Anak Jalanan," 2010. www.perspektif25.blogspot.co.id.

Lestari, Turah Asih, Pelaksanaan Pendidikan Karakter bagi Anak Jalanan dan Implikasinya terhadap Pendidikan Islam, Yogyakarta: Program Studi Pendidikan Agama Islam, Fakultas Ilmu Tarbiyah dan Keguruan, UIN Sunan Kalijaga, 2013.

M. Quraish Shihab. Membumikan Al-Quran Jilid 2. Jakarta: Lentera Hati, 2011.

- - - Tafsir Al-Mishbah. Jakarta: Lentera Hati, 2011.

Malayu S. P. Hasibuan. Manajemen Sumber Daya Manusia. Cetakan ke-12. Jakarta: Bumi Aksara, 2009. 
Maryam Namazie. Child Veiling", Multicultural and Child Protection in Britain: Sharia Law and Other Failures,. Vol. 32-34. London: One Law for All, 2013. www.onelawforall.org.uk.

Murphy, Fionnuala, "Sharia Law in the UK: Compromising Woman and Children's Safety," Multicultural and Child Protection in Britain: Sharia Law and Other Failures, London: One Law for All, 2013, 20-31, diakses tanggal 3 Maret 2016, dari www.onelawforall.org.uk.

Musfir bin Said Az-Zahrani. Konseling Terapi. Jakarta: Gema Insani, 2005.

Muslimin, Abdul Aziz, Peranan Pendidikan Islam bagi Komunitas Anak Jalanan di Kota Makassar, 2013, diunduh tanggal 11 Oktober 2015, dari www.azizmuslimi.blogspot.co.id.

Namazie, Maryam, "Child Veiling", Multicultural and Child Protection in Britain: Sharia Law and Other Failures, London: One Law for All, 2013, 32-34, diakses tanggal 3 Maret 2016, dari www.onelawforall.org.uk.

Nandika, Doni, Pendidikan di Tengah Gelombang Perubahan, Jakarta: Pustaka LP3ES Indonesia, 2007.

Pia Karlsson, dan Amir Mansory. An Afghan Dilemma: Education, Gender and Globalisation in an Islamic Context. Swedia: Institute of International Education, Department of Education Stockholm University, 2007.

Prince A Cumming. Factors Related to the Street Children Phenomenon in Major Town in Sierra Leone: Comparative Study of the City's Street Children and Children in Normal Family Home. St. Clements Uviversity, t.t. www.stclements.edu.

- - - Factors Related to the Street Children Phenomenon in Major Town in Sierra Leone: Comparative Study of the City's Street Children and Children in Normal Family Homes. St. Clements Uviversity, 2015. www.stclements.edu.

Rayan, Sobhi, "Islamic Philosophy of Education", International Journal of Humanities and Soccial Science, Vol.2 No. 19, October 2012, Israel: Department of Education, Alqasemi Academy Collage, diunduh tanggal 11 September, dari www.ijhssnet.com.

Shihab, Umar, Kontekstualitas Al-Quran: Kajian Tematik atas Ayat-Ayat Hukum dalam AlQuran, Jakarta: Penamadani, 2005.

Shihab, M. Quraish, Membumikan Al-Quran Jilid 2, Jakarta: Lentera Hati, 2011.

- - - Tafsir Al-Mishbah, Jakarta: Lentera Hati, 2011.

Shimelis Kassa Kebede. "The Situation of Street Children in Urban Centers of Ethiopia and the Role of NGOs in Addressing their Socio-Economic Problem: The Case 
of Hawassa City." International journal Academic Research in Education and Review, International journal Academic Research in Education and Review, 3(3) (April 2015): 45-57.

Siti Mujaiah. "Pendekatan Humanis dalam Pembinaan Agama Islam bagi Anak Jalanan." Universitas Islam Negeri Yogyakarta, n.d.

Sobhi Rayan. "Islamic Philosophy of Education", International Journal of Humanities and Soccial Science. Vol. Vol.2. 19. Israel: Department of Education, Alqasemi Academy Collage, 2012. www.ijhssnet.com.

Sobur, Alex, Psikologi Umum dalam Lintasan Sejarah, cetakan II, Bandung: Pustaka Setia, 2009.

Syaifuddin Zuhri. "Peran Keluarga dalam Pendidikan Akhlak Anak Jalanan: Studi Kasus Anak Jalanan di Kawasan Tugu muda Semarang." Fakultas Tarbiyah, Institut Agama Islam Negeri Walisongo, 2011. www.library.walisongo.ac.id.

Syaiful Bahri Djamarah. Psikologi Pendidikan. II. Jakarta: Rineka Cipta, 2011.

Tilaar, H.A.R., Perubahan Sosial dan Pendidikan: Pengantar Pedagogik Transformatif untuk Indonesia, Jakarta: Rineka Cipta, 2012.

- - - Pedagogik Teoritis untuk Indonesia. Jakarta: Kompas, 2015.

Turah Asih Lestari. "Pelaksanaan Pendidikan Karakter bagi Anak Jalanan dan Implikasinya terhadap Pendidikan Islam." Program Studi Pendidikan Agama Islam, Fakultas Ilmu Tarbiyah dan Keguruan, UIN Sunan Kalijaga, 2013.

Umar Shihab. Kontekstualitas Al-Quran: Kajian Tematik atas Ayat-Ayat Hukum dalam AlQuran. Jakarta: Penamadani, 2005.

Zakiah Daradjat. Metodik Khusus Pengajaran Agama Islam. Jakarta: Bumi Aksara, 2004.

Zuhri, Syaifuddin, Peran Keluarga dalam Pendidikan Akhlak Anak Jalanan: Studi Kasus Anak Jalanan di Kawasan Tugu muda Semarang, Semarang: Fakultas Tarbiyah, Institut Agama Islam Negeri Walisongo, 2011, diunduh tanggal 11 Oktober 2015, dari www.library.walisongo.ac.id. 